\title{
Acaricidal effects of seven Brazilian plant extracts
}

\author{
Efecto acaricida de siete extractos de plantas brasileñas
}

\author{
ZENEIDA TEIXEIRA PINTOO ${ }^{1,2}$, JULIANA FERREIRA CARNEIRO ${ }^{1,2}$, CÉSAR CARRIÇO $^{1,3}$, \\ REBECCA LEAL CAETANO ${ }^{1,3,4}$, VÍTOR DOS SANTOS BAIA FERREIRA ${ }^{5}$, PALOMA MARTINS MENDONÇA ${ }^{6}$, \\ ANA LUIZA RANGEL BERENGER ${ }^{7}$ and MARIA RAQUEL FIGUEIREDO ${ }^{7}$
}

\begin{abstract}
This investigation was carried out to evaluate the effects of the plant extracts of Rheedia longifolia (Clusiaceae), Garcinia xanthochymus (Clusiaceae), Plumbago scandens (Plumbaginaceae), Hovenia dulcis (Rhamnaceae), Malpighia glabra (Malpighiaceae), Euphorbia tirucalli (Euphorbiaceae) and Nerium adelfa (Apocynaceae) on eggs of Dermacentor (Anocentor) nitens and Ripicephalus sanguineus (Acari: Ixodidae) at concentrations of 1,000 ppm. The extracts had a significant effect on the hatching rate of eggs. The extracts of R. longifolia, H. dulcis, M. glabra and E. tirucalli delayed the hatching of $R$. sanguineus eggs by three days; however, the group treated with the extracts of $G$. xanthochymus and P. scandens did not hatch until day fourteen. For the tick D. (A.) nitens, extracts of $H$. dulcis and $N$. oleander delayed egg hatching by three days; however, the action of extracts from $R$. longifolia, G. xanthochymus, $P$. scandens and E. tirucalli caused a delay of seven days. For the control groups of both species, eggs hatched in one day. $H$. dulcis and M. glabra were effective in vitro on eggs of $R$. sanguineus and D. (A.) nitens (89 and $100 \%$, respectively), and can be considered to be potential candidates for the biocontrol of those ticks.
\end{abstract}

Key words: Botanical acaricide, control, arthropod, tick.

Resumen: Esta investigación se llevó a cabo para evaluar los efectos de los extractos de Rheedia longifolia (Clusiaceae), Garcinia xanthochymus (Clusiaceae), Plumbago scandens (Plumbaginaceae) Hovenia dulcis (Rhamnaceae), Malpighia glabra (Malpighiaceae), Euphorbia tirucalli (Euphorbiaceae) y Nerium adelfa (Apocynaceae) sobre la tasa incubación de los huevos de Dermacentor (Anocentor) nitens y Ripicephalus sanguineus (Acari: Ixodidae) en concentraciones de $1.000 \mathrm{ppm}$. Los extractos de R. longifolia, H. dulcis, M. glabra y E. tirucalli retrasaron significativamente la incubación de los huevos de $R$. sanguineus en tres días, pero los grupos tratados con los extractos de G. xanthochymus y P. scandens eclosionaron después de 14 días. Para las garrapatas $D$. (A.) nitens, los extractos de $H$. dulcis y $N$. adelfa retrasaron la eclosión de los huevos durante tres días, sin embargo, la acción de los extractos de R. longifolia, G. xanthochymus, $P$. scandens y E. tirucalli causó un retraso mayor de siete días. Para los dos tipos de garrapatas, los huevos del grupo control tardaron un día para eclosionar. Los extractos $H$. dulcis y M. glabra fueron eficaces in vitro en huevos de $R$. sanguineus $(89 \%)$ y $D$. (A.) nitens $(100 \%)$ y se pueden considerar como candidatos potenciales para el control biológico de estas garrapatas.

Palabras clave: Acaricida botánico, control, artrópodo, garrapata.

\section{Introduction}

Dermacetor (Anocentor) nitens (Neumann, 1897) is a tick species that causes several serious problems as a drop-in productivity and can lead to loss of the pinna by secondary bacterial invasion (Pfeifer-Barbosa 1993; Suzuki et al. 2003). The brown tick Rhipicephalus sanguineus (Latreille, 1806) is a natural ectoparasite of domestic dog and can parasitize different hosts, including man (Venzal et al. 2003; Louly et al. 2006; Ribeiro et al. 2006).

Controlling these ticks is difficult because of the increase of some strains of resistance to acaricides such as pyrethroids and the inefficacy of other compounds (Fernandes and Freitas 2001; Miller et al. 2001), so new agents and alternative strategies are necessary. According to Gionetto and Chávez (2000), metabolites of plant origin reduce the persistence and accumulation of pesticides in the environment, being biodegradable and showing no side effects.
The use of secondary phytochemical metabolites has been able to interfere with the physiology of arthropod such as neuroendocrine systems, feeding, metamorphosis, which are vulnerable points for population control based on the life cycle of arthropods (Garcia and Azambuja 2004).

Some studies revealed satisfactory results from the use of several plants substance for insect and tick management such as brow dog tick $R$. sanguineus (Acari: Ixodidae) (Denardi et al. 2010; Pinto et al. 2011), cow tick Rhipicephalus (Boophilus) microplus (Canestrini, 1887) (Acari: Ixodidae) (Borges et al. 2011); mites of the honeybees Varroa destructor Anderson and Trueman (2000) (Acari: Varroidae) (Ghasemi et al. 2011); the maize weevil adults, Sitophilus zeamais Motschulky, 1885 (Coleoptera: Curculionidae) (Fazolin et al. 2007); housefly and blowflies (Insecta: Diptera) (Carriço et al. 2014; Pinto et al. 2015a, b) and Diaphorina citri Kuwayama, 1908 (Hemiptera: Liviidae) (Mendoza-García et al. 2015).

\footnotetext{
${ }^{1}$ Instituto Oswaldo Cruz/Fundação Oswaldo Cruz (IOC/FIOCRUZ), Avenida Brasil, 4365, CEP 21040-900, Rio de Janeiro, RJ, Brasil. http://www.ioc.fiocruz.br. ${ }^{2}$ Ph. D.; B. Sc.; Fundação Oswaldo Cruz, Laboratório de Educação em Ambiente e Saúde, Rio de Janeiro, RJ, Brasil, zeneida@ioc.fiocruz.br. ${ }^{3}$ Ph. D. Fundação Oswaldo Cruz, Laboratório de Referência Nacional em Vetores das Riquetsioses, Rio de Janeiro, RJ, Brasil. ${ }^{4}$ Ph. D. Fundação Oswaldo Cruz, Programa de Pós-graduação em Biodiversidade e Saúde. Rio de Janeiro, RJ, Brasil. ${ }^{5}$ M. Sc.; Genetic Ph. D. Student, Universidade Federal do Rio de Janeiro - UFRJ, Rio de Janeiro, RJ, Brasil, vitor_baia_86@hotmail.com. ${ }^{6}$ Instituto Oswaldo Cruz/Fundação Oswaldo Cruz (IOC/FIOCRUZ), Laboratório de Entomologia Médica e Forense, Av. Brasil, 4365 - Pavilhão Herman Lent, Sala 14, Térreo. CEP 21040-900, Rio de Janeiro, RJ, Brasil. http://www.ioc. fiocruz.br. ${ }^{7}$ Ph. D. Fundação Oswaldo Cruz, FIOCRUZ, Laboratório de Química de Produtos Naturais - Instituto de Tecnologia em Fármacos, Rio de Janeiro, RJ, Brasil. http://www.ioc. fiocruz.br. Corresponding author: Zeneida Teixeira Pinto. Ph. D.; Instituto Oswaldo Cruz/Fundação Oswaldo Cruz (IOC/FIOCRUZ), Laboratório de Educação em Ambiente e Saúde. Avenida Brasil, 4365, CEP 21040-900, Rio de Janeiro, RJ, Brasil. http://www.ioc.fiocruz.br, zeneida@ioc.fiocruz.br.
} 
Searching for alternative anti-tick products led to this study which had the aim to test the acaricidal effects of Rheedia longifolia Planch and Triana (Clusiaceae), commonly known as "Bacupari", Garcinia xanthochymus Hook f (Clusiaceae), commonly known as "Falso Mangostão", Plumbago scandens L. (Plumbaginaceae), commonly known as "Bela Emília", Hovenia dulcis Thunb ( Rhamnaceae), commonly known as "Uva do Japão", Malpighia glabra L. (Malpighiaceae), commonly known as "Acerola", Euphorbia tirucalli L. (Euphorbiaceae), commonly known as "Aveloz" and Nerium oleander L. (Apocynaceae), commonly known as "Espirradeira" on the eggs of D. (A.) nitens and R. sanguineus (Acari: Ixodidae). Some of these plants have been reported possess insecticidal properties, but their acaricidal properties have not been investigated until now.

\section{Materials and methods}

Fresh leaves of the plants R. longifolia, G. xanthochynus, $P$. scandens, H. dulcis, M. glabra, E. tirucalli and N. oleander, were dried at $40{ }^{\circ} \mathrm{C}$ in an oven with air circulation and reduced to small fragments. The dried plant materials were submitted to a static extraction with methanol for about seven days and dried under reduced pressure. The crude extracts were prepared at the Instituto de Tecnologia em Fármacos/ FIOCRUZ, by researchers from the Laboratório de Produtos Naturais. The extracts were diluted in distilled water, in order to obtain the concentration of $1,000 \mathrm{ppm}$.

Gravid females of $R$. sanguineus and $D$. (A.) nitens were collected from naturally infested dogs and horses, respectively, in Rio de Janeiro-RJ. The females were placed in BOD incubators acclimatized to $27 \pm 1^{\circ} \mathrm{C}, 80 \% \mathrm{RH}$ and a 12:12 h light/dark photoperiod. In order to obtain eggs of the same age cohort, eggs from $R$. sanguineus and $D$. (A.) nitens were counted under a dissecting scope and divided into four replicates per extracts, totalizing 48 eggs per group. The eggs were placed in filter paper envelopes $(4.0$ x $5.5 \mathrm{~cm})$ and immersed for three seconds in $200 \mathrm{~mL}$ of the extracts in a Becker (Bicalho et al. 2001); distilled water was used as control. Subsequently, the eggs were transferred to an apparatus similar to the one proposed by Fernandes (1997). This apparatus was constructed with a Petri dish $(9.4 \times 1.5$ $\mathrm{cm})$ with filter paper adhered to the top part. The eggs were incubated at $27 \pm 1{ }^{\circ} \mathrm{C}, 80 \% \mathrm{RH}$ and with a $12: 12 \mathrm{~h}(\mathrm{~L}: \mathrm{D})$ $\mathrm{hr}$ cycle and daily examined until the end of the observation period. Hatched eggs were counted after 24 hours of exposure and the observation lasted four weeks. The experimental design was completely randomized, with four replicates; the treatments were constituted by the control (water distilled), as well as solutions with $200 \mathrm{~mL}$ of the extracts.

The significance of the data was evaluated by ANOVA and Tukey's test $(\mathrm{P}<0.05)$. The difference between the percentages of hatching eggs of $R$. sanguineus and $D$. (A.) nitens were evaluated through the chi-square test (Sokal and Rohlf 1979). The hatching percentage was calculated concerning the number of hatched larvae divided by the total number of incubated eggs.

\section{Results and discussion}

The efficacy of the extracts against eggs of $R$. sanguineus and $D$. (A.) nitens were assessed by measuring hatchability of eggs. There was a significant difference in the percentage of hatched eggs among treatments for the species $R$. sanguineus $\left(\chi^{2}=568.496, \mathrm{DF}=7, \mathrm{P}<0.01\right)($ Table 1$)$ and for the species $D$. (A.) nitens $\left(\chi^{2}=919.337, \mathrm{DF}=6, \mathrm{P}<0.01\right)$ (Table 2$)$.

The extracts of $R$. longifolia, H. dulcis, M. glabra and $E$. tirucalli delayed hatching of eggs of $R$. sanguineus by three days, but the group treated with the extracts of G. xanthochymus and P. scandens just hatched on day 14 . For the tick D. (A.) nitens, the extracts of $H$. dulcis and $N$. oleander delayed by three days the eggs hatching, however, the action of extracts $R$. longifolia, G. xanthochymus, $P$. scandens and E. tirucalli caused a delay of seven days. For the two control groups, the eggs hatched in one day. Pinto et al. (2011) evaluated the acaricidal activity of the latex from Euphorbia splendens var. hislopii (Euphorbiaceae) and verified that eggs of $R$. sanguineus treated with $25 \mu \mathrm{L} / \mathrm{L}$ began hatching $24 \mathrm{~h}$ after treatment, while for the groups treated with other concentrations $(50,100,125,250$ and 500 $\mu \mathrm{L} / \mathrm{L}$ ), the hatchings began $72 \mathrm{~h}$ after exposure.

Shafy and Zayed (2002) using a different methodology, showed that when eggs of Hyalomma (Anatolicum) excavatum (Acari: Ixodidae) are immersed in neem extracts in vitro, the hatching accelerates, and the mortality of newly hatched larvae increases. Extracts of $M$. azedarach inhibit egg production of immersed Rhipicephalus (B.) microplus ticks (Borges et al. 2003). According to Silva et al. (2009) Hexanic, ethyl acetate and ethanolic extracts from leaves of Piper aduncum (Piperaceae) were tested against engorged females of Rhipicephalus (B.) microplus. For all extracts, even at the highest concentration, reproductive control was

Table 1. Average of eggs hatched of Rhipicephalus sanguineus $(\mathrm{n}=192)$, per days after treatment, mean, standard deviation and eclosion (\%), exposed to different aqueous extracts of plants and control group, under laboratory conditions.

\begin{tabular}{|c|c|c|c|c|c|c|c|}
\hline \multirow{2}{*}{ Extracts } & \multicolumn{6}{|c|}{ Days after treatment } & \multirow{2}{*}{$\begin{array}{c}\text { Eggs hatched } \\
X \pm \text { S. D. }\end{array}$} \\
\hline & 1 & 3 & 7 & 14 & 21 & 28 & \\
\hline Control & 7 & 0.75 & 10 & 12.7 & 8.3 & 0 & $4.2 \pm 2.9^{\text {a }}$ \\
\hline Reedia longifolia & 0 & 0.5 & 0.25 & 4.25 & 2.25 & 0.75 & $2.7 \pm 6.5 \mathrm{ab}$ \\
\hline Garcinia xanthochymus & 0 & 0 & 0 & 1.25 & 5.75 & 0 & $2.7 \pm 6.8 \mathrm{ab}$ \\
\hline Plumbago scandens & 0 & 0 & 0 & 2.75 & 0 & 0 & $1.5 \pm 4.9^{b^{* * *}}$ \\
\hline Hoveni dulcis & 0 & 0.25 & 1 & 3.25 & 1 & 0 & $1.4 \pm 4.3^{\mathrm{b}^{* * *}}$ \\
\hline Malphighia glabra & 0 & 3.25 & 3.5 & 4 & 0.5 & 0 & $0.8 \pm 2.3^{\mathrm{bc} * * *}$ \\
\hline Euphorbia tirucalli & 0 & 2 & 1.75 & 6.25 & 2 & 0.25 & $3.4 \pm 6.6^{\mathrm{a}}$ \\
\hline Nerium oleander & 0.25 & 0.5 & 1.75 & 3.5 & 2.25 & 0 & $1.7 \pm 4.9^{\mathrm{b}^{* * *}}$ \\
\hline
\end{tabular}

Numbers followed by the same letter did not differ among themselves and those followed by different letters have a significant difference $(* \mathrm{P}<0.05, * * \mathrm{P}<0.01, * * * \mathrm{P}<0.001)$ when the Tukey test was used. 
Table 2. Average of eggs hatched of Anocentor nitens $(\mathrm{n}=192)$, per days after treatment, mean, standard deviation and eclosion (\%), exposed to different aqueous extracts of plants and control group, under laboratory conditions.

\begin{tabular}{|c|c|c|c|c|c|c|c|}
\hline \multirow{2}{*}{ Extracts } & \multicolumn{6}{|c|}{ Days after treatment } & \multirow{2}{*}{$\begin{array}{c}\text { Eggs hatched } \\
\mathrm{X} \pm \text { S. D. }\end{array}$} \\
\hline & 1 & 3 & 7 & 14 & 21 & 28 & \\
\hline Control & 12.25 & 15.5 & 18.75 & 1 & 0 & 0 & $4.2 \pm 2.9^{\mathrm{a}}$ \\
\hline Reedia longifolia & 0 & 0 & 1.25 & 0 & 0 & 0 & $0.1 \pm 1.1 \mathrm{~b} * * *$ \\
\hline Garcinia xanthochymus & 0 & 0 & 1.5 & 0.5 & 0 & 0 & $0.3 \pm 1.8^{\mathrm{bc} * * *}$ \\
\hline Plumbago scandens & 0 & 0 & 1.25 & 1.25 & 0.75 & 0 & $0.8 \pm 3.5^{\mathrm{c} * * *}$ \\
\hline Hoveni dulcis & 0 & 0.25 & 0.25 & 0 & 0 & 0 & $0.03 \pm 0.5^{\mathrm{b} * * *}$ \\
\hline Malphighia glabra & 0 & 0 & 0 & 0 & 0 & 0 & $0.0 \pm 0.0^{\mathrm{b} * * *}$ \\
\hline Euphorbia tirucalli & 0 & 0 & 0.5 & 0 & 0.25 & 0 & $0.1 \pm 1.6^{\mathrm{b} * * *}$ \\
\hline Nerium oleander & 0 & 3.75 & 2.25 & 0 & 0.5 & 0 & $0.7 \pm 2.6^{\mathrm{bc} * * *}$ \\
\hline
\end{tabular}

Numbers followed by the same letter did not differ among themselves and those followed by different letters have a significant difference $(* \mathrm{P}<0.05, * * \mathrm{P}<0.01, * * * \mathrm{P}<0.001)$ when the Tukey test was used.

no higher than $62 \%$. Hexanic extracts caused larvae mortality of $70.42 \%$ and, its hydrodistillation produced $6.8 \%$ essential oil, $94.84 \%$ consisting on the sesquiterpene dill apiol, which caused $100 \%$ larval mortality.

Some experiments have demonstrated that plants extracts interfere with tick oviposition, by acting directly on growth control and development (Borges et al. 2003; Silva et al. 2009; Ribeiro et al. 2010; Silva et al. 2011). The $H$. dulcis extracts inhibited $89 \%$ of the $R$. sanguineus eggs to hatch. Among secondary metabolites found in $H$. dulcis were triterpene saponins, glycosides, triterpenes and dihydroflavonoids (Castro et al. 2005). Recent studies of chemistry and pharmacology activity of $H$. dulcis have shown promising potential as a bioactive species, especially due to its antineoplastic activity (Martínez et al. 1997; Popoca et al. 1998). They also reported a $95 \%$ trypanocidal inhibition by the aqueous extracts and $100 \%$ inhibition for the methanolic extracts from the leaves of plants.

The extracts from the plants $G$. xanthochymus, $P$. scandens, $N$. oleander and $R$. longifolia reduced hatchability of $R$. sanguineus eggs by $85,85,84$ and $83 \%$, respectively, but the newly hatched larvae died just after eclosion. Extracts from M. glabra and E. tirucalli showed $76 \%$ ovicidal activity. The data showed that the extracts act directly on the biology of the tick $R$. sanguineus.

Eggs of the tick $D$. (A.) nitens treated with aqueous extracts from M. glabra, presented $100 \%$ of mortality, which suggests that it produces a substance that affects embryo development. It was observed that extracts $H$. dulcis, E. tirucalli, R. longifolia, G. xanthochymus and P. scandens prevented hatching of $D$. (A.) nitens eggs in 99, 98, 97, 96 and $93 \%$, respectively. $N$. oleander extracts was less active and caused only an $85 \%$ ovicidal effects. For the control group, the egg hatching rate was of approximately $99 \%$ for the two species of tick studied.

The results obtained by Pinto et al. (2011), using latex of E. splendens var. hislopii on eggs of $R$. sanguineus showed that the lowest number of eclosions was observed at higher concentrations 125,250 and $550 \mathrm{~mL}(1 \%$ for these concentrations), but the newly hatched larvae died just after eclosion. For the other concentrations tested, the egg hatching rates were $45 \%$ at $25 \mu \mathrm{L}, 30 \%$ at $100 \mu \mathrm{L}$. This was confirmed by those extracts of Artocarpus alitilis (Moraceae) and Azadirachta indica (Meliaceae) on R. (B.) microplus eggs, and we observed unfeasible hatching in 65 and $80 \%$, respectively.
Results found in this research are in agreement with other authors who have studied the effects of Neem Azal F (Trifolio-M GmbH, Germany) seed extracts against the postembryonic development and adults of $H$. (A.) excavatum (acari: Ixodidae). They found that neem at concentrations of 1.6 and $3.2 \%$ significantly affects this species of tick (Shafy and Zayed 2002).

Our data suggest that the bioassays conducted offered excellent results for the potential activity of the samples, particularly in relation to the extracts of $H$. dulcis and $M$. glabra that produced ovicidal action, preventing hatching of the eggs of $R$. sanguineus (89\%) and $D$. (A.) nitens (100 $\%$ ), respectively. As a result, the unhatched eggs were pale and showed rough surfaces morphologically altered and the embryos become opaque within the shell.

These extracts could play an important role in the future to control the ticks. Anyway, the isolation and characterization of the active compounds of each extract and the minimum dosage necessary to achieve the desired effects still depends on further studies to be properly defined.

The results indicated a significant effect of extracts from $R$. longifolia, G. xanthochymus, $P$. scandens, H. dulcis, M. glabra, E. tirucalli and $N$. oleander on embryonated eggs from $R$. sanguineus and $D$. (A.) nitens.

\section{Acknowledgements}

This work was financially supported by CAPES (Coordenação de Aperfeiçoamento de Pessoal de Nível Superior) and Instituto Oswaldo Cruz/Fundação Oswaldo Cruz (IOC/ FIOCRUZ) for grants and scholarships. We would like to thank Paulo Vander Ferreira Santana for the English review.

\section{Literature cited}

ANDERSON, D. L. TRUEMAN, J. W. H. 2000. Varroa jacobsoni (Acari: Varroidae) is more than one species. Experimental and Applied Acarology 24 (3): 165-189.

BICALHO, K. A.; FERREIRA, F.; BORGES, L. M. F.; RIBEIRO, M. F. B. 2001. In vitro evaluation of the effects of some acaricides on life stages of Rhipicephalus sanguineus (Acari: Ixodidae). Arquivo Brasileiro de Medicina Veterinária e Zootecnia 53: 548-552.

BORGES, L. F.; FERRI, P. H.; SILVA, W. J.; SILVA, W. C.; SILVA, J. G. 2003. In vitro efficacy of extracts of Melia azedarach against the tick Boophilus microplus. Medical and Veterinary Entomology 17: 228-231. 
BORGES, L. M. F.; SOUSA, L. A. D.; BARBOSA, C. S. 2011. Perspectives for the use of plant extracts to control the cattle tick Rhipicephalus (Boophilus) microplus. Revista Brasileira de Parasitologia Veterinaria 20 (2): 89-96.

CARRIÇO, C. S.; PINTO, Z. T.; DUTOK, C. M. S.; CAETANO, R. L.; PESSANHA, R. R.; CHIL - NUNEZ, I.; MENDONÇA, P. M.; ESCALONA-ARRANZ, J.; REYES-TUR, B.; QUEIROZ, M. M. C. 2014. Biological activity of Pouteria sapota leaf extract on post-embryonic development of blowfly Chrysomya putoria (Wiedemann, 1818) (Calliphoridae). Revista Brasileira de Farmacognosia 24 (3): 304-308.

CASTRO, T. C.; BARBOSA, K. C.; Albarello, N.; FIGUEIREDO, S. F. L. 2005. Caracterização de pseudofrutos, frutos, sementes e plântulas obtidas a partir de germinação in vivo e in vitro da espécie medicinal Hovenia dulcis (Rhamnaceae). Revista Cubana de Plantas Medicinales 10: 1-16.

DENARDI, S. E.; BECHARA, G. H.; OLIVEIRA, P. R.; CAMARGO-MATIAS, M. I. 2010. Azadirachta indica, A. Juss (neem) induced morphological changes on oocytes of Rhipicephalus sanguineus (Latreille, 1806) (Acari: Ixodidae) tick females. Experimental Parasitology 126 (4): 462-470.

FAZOLIN, M.; ESTRELA, J. L. V.; CATANI, V.; ALÉCIO, M. R.; LIMA, S. L. 2007. Atividade inseticida do óleo essencial de Tanaecium nocturnum (Barb. Rodr.) Bur. \& K. Shum (Bignoneaceae) sobre Sitophilus zeamais Motsch. (Coleoptera: Curculionidae). Acta Amazonica 37 (4): 599-603.

FERNANDES, F. F. 1997. Dispositivo experimental para manutenção de colônias de ixodídeos visando ao estudo dos parâmetros biológicos da fase de vida livre do ciclo evolutivo. Revista Goiana de Medicina 42: 43-48.

FERNANDES, F. F.; FREITAS, E. P. S. 2001. Analysis of the use of fenthion via epicutaneous in dogs for Rhipicephalus sanguineus control. Revista da Sociedade Brasileira de Medicina Tropical 34: 339-342.

GARCIA, E. S.; AZAMBUJA, P. 2004. Lignoids in insects: chemical probes for the study of ecdysis, excretion and Trypanosoma cruzi-triatomine interactions. Toxicon 44: 431-440.

GIONETTO, F.; CHÁVEZ, E. C. 2000. Desarrollo actual de las investigaciones alelopaticas de la producción de insecticidas botánicos en Michoacán (México). pp. 123-134. In: Memórias do Simposio Nacional Sobre Substancias Vegetales y Minerales em el Combate de Plagas, Abstracts, Acapulco, Mexico.

GHASEMI, V.; MOHARRAMIPOUR, S.; TAHMASBI, G. 2011. Biological activity of some plant essential oils against Varroa destructor (Acari: Varroidae), an ectoparasitic mite of Apis mellifera (Hymenoptera: Apidae). Experimental and Applied Acarology 55 (2): 147-154

LOULY, C. C. B.; FONSECA, I. N.; OLIVEIRA, V. F. 2006. Ocorrência de Rhipicephalus sanguineus em trabalhadores de clínicas veterinárias e canis, no município de Goiânia, GO. Ciência Animal Brasileira 7: 103-106.

MARTÍNEZ, F. J.; DURÓN, R. R.; TORRES, N. W.; PIÑEYROLÓPEZ, A. 1997. Experimental evidence for toxic damage induced by a dimeric anthracenone: diast T-514 (peroxisomicine A2). Toxicology Letters 90: 152-162.

MENDOZA-GARCÍA, E. E.; ORTEGA-ARENAS, L. D.; CRUZ, M. A. S.; CEDILLO, F. D.; VILLANUEVA-JIMÉNEZ, J. A.; LÓPEZ-ARROYO, J. I.; PÉREZ-PACHECO, R. 2015. Efecto biológico del aceite de Tagetes coronopifolia (Asteraceae) contra Diaphorina citri (Hemiptera: Liviidae). Revista Colombiana de Entomología 41 (2): 157-162.

MILlER, R. J.; GEORGE, J. E.; GERREIRO, F. 2001. Characterization of Acaricide Resistance in Rhipicephalus sanguineus (Latreille) (Acari: Ixodidae) collected from the Corozal Army Veterinary Quarantine Center, Panama. Journal of Medical Entomology 38: 293-302.

PFEIFER-BARBOSA, I. B. 1993. Epidemological studies of infections with Babesia equi and Babesia caballi in Brazil.
Medical Veterinary Dissertation, School of Veterinary Medicine, Hanover. Germany. 34 p.

PINTO, Z. T.; QUEIROZ, M. M. C.; BARBOSA, J. V. 2011. Efficiency of latex from Euphorbia splendens var. hislopii (N.E.Br.) Ursch \& Leandri, Euphorbiaceae, in the control of Rhipicephalus (Boophilus) sanguineus (Latreille, 1806) (Acari: Ixodidae). Revista Brasileira de Farmacognosia 21: 432-436.

PINTO, Z. T.; FERNÁNDEZ-SÁNCHEZ, F.; SANTOS, A. R.; AMARAL, A. C. F.; FERREIRA, J. L. P.; ESCALONAARRANZ, J. C.; QUEIROZ, M. M. C. 2015a. Effect Chemical composition and insecticidal activity of Cymbopogon citratus essential oil from Cuba and Brazil against house fly. Revista Brasileira de Parasitologia Veterinária Jaboticabal 24 (1): 36-44.

PINTO, Z. T.; FERNÁNDEZ-SÁNCHEZ, F.; SANTOS, A. R.; AMARAL,A.C.F.; FERREIRA, J. L. P.; ESCALONA-ARRANZ, J. C.; QUEIROZ, M. M. C. 2015b. Effect of Cymbopogon citrates (Poaceae) oil and citral on post-embryonic time of blowflies. Journal of Entomology and Nematology 7 (6): 54-64.

POPOCA, J.; AGUILAR, A.; ALONSO, D.; VILLARREA, M. L. 1998. Cytotoxic activity of selected plants used as antitumorals in Mexican traditional medicine. Journal of Ethnopharmacology 59: 173-177.

RIBEIRO, F. A.; FERNANDES, J. I.; CORREIA, T. R. 2006. Eficácia "in vitro" de diferentes acaricidas no controle de fêmeas ingurgitadas de Rhipicephalus sanguineus. In: Congresso Brasileiro de Parasitologia Veterinária e Simpósio Latinoamericano de Riquetsioses, 14. Ribeirão Preto. Annais. Ribeirão Preto: [s. n.] 225 p.

RIBEIRO, V. L.; DOS SANTOS, J. C.; BORDIGNON, A. S.; APEL, M. A.; HENRIQUES, A. T.; VON POSER, G. L. 2010. Acaricidal properties of the essential oil from Hesperozygis ringens (Lamiaceae) on the cattle tick Rhipicephalus (Boophilus) microplus. Bioresource Technology 101: 2506-2509.

SHAFY, A. S.; ZAYED, A. A. 2002. In vitro acaricidal effect of plant extract of neem seed oil (Azadirachta indica) on egg, immature, and adult stages of Hyalomma anatolicum excavatum (Ixodoidea: Ixodidae). Veterinary Parasitology 106: 89-96.

SILVA, W. C.; MARTINS, J. R. S.; SOUZA, H. E.M.; HEINZEN, H. CESIO, M. V.; MATO, M.; ALBRECHT, F.; AZEVEDO, J. L.; BARROS, N. M. 2009. Toxicity of Piper aduncum L. (Piperales: Piperaceae) from the Amazon Forest for the cattle tick Rhipicephalus (Boophilus) microplus (Acari: Ixodidae). Veterinary Parasitology 164: 267-274.

SILVA, W. C.; MARTINS, J. R. S.; CESIO, M. V.; AZEVEDO, J. L.; HEINZEND, H.; BARROS, N. M. 2011. Acaricidal activity of Palicourea marcgravii, a species from the Amazon forest, on cattle tick Rhipicephalus (Boophilus) microplus. Veterinary Parasitology 79: 189-194.

SOKAL, R. R.; ROHLF, F. J. 1979. Biometry. 3. ed. New York. Freeman. $776 \mathrm{p}$.

SUZUKI, E. M.; SILVA, W. W.; COSTA, G. L.; BITTENCOURT, V. R. E. P. 2003. Infecção de órgãos internos de fêmeas ingurgitadas de Anocentor nitens (Acari: Ixodidae) por Metarhizium anisopliae. Revista Brasileira de Parasitologia Veterinária 2: 85-87.

VENZAL, J. M.; GUGLIELMONE, A. A.; ESTRADA-PENA, A. 2003. Ticks (Ixodida: Ixodidae) parasitising humans in Uruguay. Annals of Tropical Medicine and Parasitology 97: 769-77.

Received: 23-Feb-2017 • Accepted: 05-Nov-2017

Suggested citation:

PINTO, Z. T.; CARNEIRO, J. F.; CARRIÇO, C.; CAETANO, R. L.; FERREIRA, V. S. B.; MENDONÇA, P. M.; BERENGER, A. L. R.; FIGUEIREDO, M. R. 2018. Acaricidal effects of seven Brazilian plant extracts. Revista Colombiana de Entomología 44 (1): 44-47. Enero - Junio 2018. 